\title{
Revisi taksonomi Bloom: Kognitif, afektif, dan psikomotorik
}

\author{
Dewi Amaliah Nafiati \\ Universitas Pancasakti Tegal, Indonesia \\ Email:nafiatilia@gmail.com
}

\begin{abstract}
Abstrak
Revisi taksonomi Bloom menitikberatkan pada (1) perubahan aplikasi yang terdiri dari tiga bidang yaitu aplikasi bidang penyusunan kurikulum, aplikasi bidang instruksi pengajaran, aplikasi bidang assesment/ penilaian; dan (2) perubahan terminologi yang menekankan pada sub kategori sehingga penilaian menjadi lebih spesifik, mudah dalam menyusun penilaian pada kurikulum, serta mudah dalam menyusun instruksi pengajaran. Revisi taksonomi Bloom juga mengubah kata kunci operasional dari kata benda menjadi kata kerja dari level terendah sampai dengan level tertinggi.Terdapat perubahan yang sangat signifikan pada revisi taksonomi Bloom di domain kognitif yang terdiri dari dua dimensi yaitu dimensi pengetahuan dan dimensi proses kognitif. Dimensi pengetahuan berubah menjadi faktual, konseptual, prosedural, metakognisi. dimensi proses kognitif baru menjadi mengingat, memahami, mengaplikasikan, menganalisis, mengevaluasi, dan mencipta. Domain afektif meliputi rasa, nilai, apresiasi, antusiasme, motivasi, dan sikap tercermin pada perilaku/ attitude sehari-hari pada proses pembelajaran baik di dalam kelas maupun di luar kelas. Domain psikomotorik dirumuskan sebagai serangkaian kemampuan yang bersifat kongkrit dan abstrak.
\end{abstract}

Keywords: Bloom, Kurikulum, Penilaian 


\section{Abstract}

Bloom's taxonomic revision focuses on (1) application changes that consist of three fields, namely the application of curriculum development. application of teaching instruction area, application of assessment/ assessment field; and (2) changes in the terminology emphasizing sub-categories so that assessment becomes more specific, it is easy to arrange assessments in the curriculum, and easy to arrange instructions teaching. Revised Bloom's taxonomy also changed the operational keywords from words to verbs from the lowest level to the highest level. There is a very significant change in Bloom's revised taxonomy in the cognitive domain which consists of two dimensions, namely the dimension of knowledge and the dimension of cognitive processes. The dimension of knowledge changes into factual, conceptual, procedural metacognition. the dimension of the new cognitive process becomes remembering, understanding apply. analyze, evaluate and create. Affective domain includes taste, value, appreciation, enthusiasm, motivation. and attitudes are reflected in behavior everyday in the learning process both in the classroom and outside the classroom. Domain psychomotor formulated as a series of abilities that are concrete and abstract.

Keywords: Bloom, Curriculum, Assessment

\section{Pendahuluan}

Sumber daya manusia yang berkualitas merupakan faktor utama berkembang dan majunya sebuah negara dan bangsa. Sumber daya manusia juga menjadi fokus utama dalam era revolusi industri 4.0. berbagai macan upaya dilakukan oleh pemerintah dalam ranga pemenuhan sumber daya yang berkualitas sebagai jawaban atas tantangan revolusi industri 4.0. melalui kementeriannya, pemerintah memberikan kesempatan kepada masyarakat untuk ikut serta dalam proses pendidikan baik formal (sekolah) maupun non formal (komunitas-komunitas, pelatihan-pelatihan, pemagangan-pemagangan dan sertifikasi kompetensi atau keahlian yang diakui oleh pemerintah).

Terkait dengan pendidikan, merupakan investasi yang sangat penting dalam rangka menghadapi dunia yang semakin kompleks dan berkembang secara sangat signifikan. Berdasarkan teori human capital "Pendidikan merupakan investasi sumber daya manusia yang banyak memberikan manfaat, seperti: diperolehnya kondisi kerja yang lebih baik, efisiensi produksi, peningkatan kesejahteraan dan tambahan pendapatan seseorang apabila mampu 
menyelesaikan tingkat pendidikan yang lebih tinggi dibandingkan dengan pendapatan lulusan pendidikan di bawahnya (Gaol, 2014). Salah satu respon pemerintah dalam rangka memenuhi sumber daya manusia yang berkualitas dan mampu bersaing dengan dunia global adalah dengan menetapkan Standar Kompetensi Kerja Nasional Indonesia (SKKNI) ditetapkan oleh Pemerintah sebagai sebuah rumusan kemampuan kerja atau kompetensi yang mencakup aspek pengetahuan (knowledge/ kognitif), keterampilan (skil/psikomotor), dan sikap kerja (attitude/ afektif) yang sesuai dengan standar operasional prosedur (SOP) dari tugas atau pekerjaan dan syarat dari jabatan yang akan didudukinya. Selain itu, pendidikan berbasis karakter juga menjadi ruh dalam setiap jenjang pendidikan di Indonesia.

Pendidikan formal di Indonesia ditetapkan secara berjenjang, yang dimulai dari pendidikan dasar, pendidikan menengah, dan pendidikan tinggi (UU Sisdiknas, 2003). Masing-masing jenjang pendidikan tersebut didasarkan pada tingkat perkembangan peserta didik, tujuan pendidikan yang ingin dicapai, dan kemampuan apa yang ingin dikembangkan. Proses pendidikan yang bermutu dan berkualitas tersebut akan tercapai manakala terjadi hubungan yang sinergis antara seluruh komponen yang terlibat dalam proses pendidikan. Sebuah pertanyaan muncul, siapakah komponen pendidikan tersebut? Soetarno (2003) menyampaikan bahwa komponen dalam sistem pendidikan formal terdiri dari tujuan pendidikan, peserta didik, pendidik, metode pendidikan, isi pendidikan/ materi pendidikan, lingkungan pendidikan, alat dan fasilitas pendidikan.

Pada pendidikan formal dari sekian komponen yang terlibat, faktor guru menjadi sangat penting. Guru menurut UU no. 14 tahun 2005 "adalah pendidik profesional dengan tugas utama mendidik, mengajar, membimbing, mengarahkan, melatih, menilai, dan mengevaluasi peserta didik pada pendidikan anak usia dini jalur pendidikan formal, pendidikan dasar, dan pendidikan menengah". Guru layaknya seorang aktor yang berperan mengelola segala aktifitas pembelajaran hingga tercapainya tujuan pendidikan yang telah ditetapkan. Proses pembelajaran ekonomi pada Sekolah Menengah Atas (SMA) harus diawali dengan penyusuna serangkaian perangkat pembelajaran yang baik.

Perangkat pembelajaran ekonomi SMA diawali dengan penyusunan rencana pelaksanaan pembelajaran (RPP) dengan baik yang didasarkan pada kurikulum 2013 (kompetensi inti dan kompetensi dasar). RPP menjadi sangat penting karena RPP menjadi rambu-rambu guru dalam melaksanakan 
serangkaian perannya pada setiap kegiatan belajar mengajar. RPP yang dirancang berisi skenario yang memuat tujuan pembelajaran yang ingin dicapai pada setiap pertemuan pembelajaran. Walaupun demikian, sebaik-baik RPP disusun, tetap harus diuji tingkat ketercapaian tujuan pembelajarannya melalui penilaian. Penilaian dapat dilakukan dengan memberikan tes kepada siswa terkait dengan tujuan pembelajaran yang tertuang pada setiap RPP yang disusun. Penilaian ini menjadi sangat penting sebagai bahan masukan, koreksi, perbaikan bagi guru akan kualitas RPP yang dibuat. Tes yang disusun untuk dikerjakan oleh siswa dan dikoreksi oleh guru harus berdasarkan konsep dan materi ekonomi yang diajarkan kepada siswa. Ini menjadi salah satu tolak ukur apakah materi yang disamaikan oleh guru telah dikuasai dengan baik oleh siswa. Persentase Kriteria Ketuntasan Minimal (KKM) yang telah ditetapkan sekolah menjadi indikator yang ketercapaian tujuan pembelajaran yang tertuang dalam RPP guru.

Tes yang dibuat oleh guru menjadi instrumen penting dalam menilai ketuntasan pembelajaran siswa. Dalam penyusunan tes, banyak terlibat serngkaian kata kerja sebagai pengukuran ketercapaian tujuan pembelajaran. Taksonomi Bloom merumuskan taksonomi tujuan pendidikan dalam tiga buku, pertama domain kognitif; kedua, tahun 1964 tentang domain afektif; dan ketiga tahun 1964 tentang "Stabilitas dan Perubahan Karakteristik Manusia" yang memicu minat pada anak-anak dan pembelajaran yang pada akhirnya secara langsung mengarah pada pembentukan program Head Start di Amerika (Zhou \& Brown, 2017)

\section{Hasil dan Pembahasan}

\section{Konsep Taksonomi Bloom}

Taksonomi merupakan sistem klasifikasi (Yaumi, Muhammad: 2013) yang berasal dari bahasa Yunani dan mengandung dua arti yaitu "Taxis/ pengaturan" dan "Nomos/ ilmu pengetahuan" (Wibowo, Tri: 2007). Taksonomi Bloom berangkat dari pemikiran seorang psikolog pendidikan yaitu Dr. Benjamin Boom (1956) yang membentuk pemikiran pendidikan pada level yang lebih tinggi, yaitu menganalisis dan mengevaluasi konsep, proses, prosedur, dan prinsip, bukan hanya mengingat fakta/hafalan (Zhou \& Brown, 2017). Pada tahun 1956, Bloom menerbitkan karyanya yang berjudul "Taxonomy of Educational Objective Cognitive Domain", dilanjutkan pada tahun 1964 dengan karyanya "Taxonomy of Educataional Objectives, Affective Domain". Produktifitas Bloom tidak berhenti sampai di situ. Pada tahun 1971, Bloom berkarya kembali 
dengan mempublikasikan karyanya yang berjudul "Handbook on Formative and Summatie Evaluation of Student Learning", serta di tahun 1985 keluar kembali karya Bloom yang berjudul "Developing Talent in Young People" (Winkel, 2007).

Taksonomi Bloom banyak diterapkan ketika merencanakan tujuan belajar dan pembelajaran dan berbagai aktifitas pembelajaran. Pada awal penyusunan taksonominya, Bloom merumuskan dua domain pembelajaran yaitu domain kognitif: keterampilan mental (pengetahuan), dan domain afektif: pertumbuhan perasaan atau bidang emosional (sikap). Pada tahun 1966, Simpson merumuskan satu domain untuk melengkapi taksonomi yang dicetuskan oleh Bloom, yaitu domain psikomotor: keterampilan manual atau fisik (keterampilan). Simpson memperkenalkan "The Classification of Educational Objectives in the Pyschomotor Domain" dan Dave (1967) memperkenalkan "Psychomotor Domain".

\section{Revisi Taksonomi Bloom}

Krathwohl (2002) menyampaikan bahwa Bloom menyampaikan pemikirannya tentang taksonomi kognitif terutama dalam rangka penyusunan soal/ tes ujian untuk siswa sesuai dengan tujuan pembelajaran yang telah ditetapkan. Krathwohl yang merupakan sahabat dari Bloom bersama dengan ahli psikologi bidang pendidikan bekerja keras untuk mervisi taksonomi tersebut dan mempublikasikannya (Anderson et al., 2001). Terdapat perubahan yang mendasar dari revisi taksonomi Bloom, yaitu:

1. Revisi taksonomi Bloom menfokuskan pada perubahan aplikasi yang terdiri dari tiga bidang yaitu aplikasi bidang penyusunan kurikulum, aplikasi bidang instruksi pengajaran, aplikasi bidang assesment/ penilaian. Pada taksonomi Bloom yang lama, penyusunan taksonomi ditujukan untuk mempermudah penyusunan penilian untuk tingkat perguruan tinggi secara nasional.

2. Revisi taksonomi Bloom fokus pada perubahan terminologi, dimana revisi taksonomi Bloom menekankan pada sub kategori yang mengakibatkan penilaian menjadi lebih spesifik, mudah dalam menyusun penilaian pada kurikulum, serta mudah dalam menyusun instruksi pengajaran. Selain itu revisi taksonomi Bloom terdapat perubahan knowledge/ pengetahuan sebagai kategori menjadi sebuah ukuran yang harus dicapai. Revisi taksonomi Bloom juga mengubah kata kunci operasional dari kata benda menjadi kata kerja dari level terndah sampai dengan level tertinggi. 
Humanika, Kajian IImiah Mata Kuliah Umum, Vol. 21. No. 2. (2021), 151-172

\section{Domain Kognitif}

Domain pengetahuan/ kognitif dalam Taksonomi Bloom berkaitan dengan ingatan, berpikir dan proses-proses penalaran. Berikut revisi taksonomi Bloom pada domain kognitif yang disampaikan oleh Anderson et al. (2001).

Tabel 1. Revisi Taksonomi Bloom Domain Kognitif

\begin{tabular}{ccc}
\hline & Taksonomi Bloom Lama & Taksonomi Bloom Baru \\
\hline C1 & (Pengetahuan) & (Mengingat) \\
\hline C2 & (Pemahaman) & (Memahami) \\
\hline C3 & (Aplikasi) & (Mengaplikasikan) \\
\hline C4 & (Analisis) & (Menganalisis) \\
\hline C5 & (Sintesis) & (Mengevaluasi) \\
\hline C6 & (Evaluasi) & (Mencipta) \\
\hline
\end{tabular}

Versi baru Taxonormy Blooms dengan contoh dan kata kunci ditunjukkan pada tabel 2 .

Tabel 2. Revisi Taksonomi Bloom dan Kata Kuncinya

\begin{tabular}{|c|c|c|c|}
\hline \multicolumn{2}{|c|}{ Domain Kognitif Tua (Asli) } & \multicolumn{2}{|c|}{ Domain Kognitif Baru (Revisi) } \\
\hline Level & $\begin{array}{l}\text { Contoh, Kata Kunci (Kata } \\
\text { Kerja), dan Pembelajaran } \\
\text { Membagi dan } \\
\text { Teknologi }\end{array}$ & Level & $\begin{array}{l}\text { Contoh, Kata Kunci (Verb), } \\
\text { dan Kegiatan Belajar dan } \\
\text { Teknologi }\end{array}$ \\
\hline $\begin{array}{l}\text { Pengeta- } \\
\text { huan: Ingat } \\
\text { data atau } \\
\text { informasi. }\end{array}$ & $\begin{array}{l}\text { Contoh: Ucapkan sebuah } \\
\text { kebijakan. Mengutip harga dari } \\
\text { memori ke pelanggan. Ketahui } \\
\text { aturan keamanannya. } \\
\text { Tentukan suatu istilah } \\
\text { Kata Kunci: mengatur, mendefi- } \\
\text { nisikan, } \\
\text { menggambarkan, identitas, } \\
\text { tahu, label, daftar, kecocokan, } \\
\text { nama, menguraikan, mengingat, } \\
\text { mengenali, } \\
\text { mereproduksi, memilih, menya- } \\
\text { takan } \\
\text { Teknologi: bookmark, } \\
\text { kartu flash, pencarian internet, } \\
\text { bacaan }\end{array}$ & $\begin{array}{l}\text { Mengingat: } \\
\text { Ingat atau } \\
\text { ambil dipela- } \\
\text { jari sebelum- } \\
\text { nya } \\
\text { informasi }\end{array}$ & $\begin{array}{l}\text { Contoh: Ucapkan sebuah ke- } \\
\text { bijakan. Mengutip harga dari } \\
\text { memori ke pelanggan. } \\
\text { Bacalah aturan keselamatan. } \\
\text { Kata Kunci: mendefinisikan, } \\
\text { menjelaskan, mengidentifika- } \\
\text { si, mengetahui, label, daftar, } \\
\text { kecocokan, nama, garis besar, } \\
\text { penarikan kembali, Menga- } \\
\text { kui, mereproduksi, memilih, } \\
\text { menyatakan } \\
\text { Teknologi: penandaan buku, } \\
\text { flash kartu, belajar hafalan } \\
\text { berdasarkan pengulangan, } \\
\text { membaca }\end{array}$ \\
\hline
\end{tabular}




\begin{tabular}{|c|c|c|c|}
\hline \multicolumn{2}{|c|}{ Domain Kognitif Tua (Asli) } & \multicolumn{2}{|c|}{ Domain Kognitif Baru (Revisi) } \\
\hline $\begin{array}{l}\text { Pemahaman: } \\
\text { Memahami } \\
\text { berarti } \\
\text { terjemahan, } \\
\text { interpolasi, } \\
\text { \& } \\
\text { interpretasi } \\
\text { dari instruksi } \\
\text { dan masalah. } \\
\text { Sebutkan } \\
\text { masalah } \\
\text { dalam diri } \\
\text { seseorang } \\
\text { kata-kata } \\
\text { sendiri. }\end{array}$ & $\begin{array}{l}\text { Contoh: Menulis ulang } \\
\text { prinsip penulisan ujian, Jelaskan } \\
\text { dengan kata-kata sendiri lang- } \\
\text { kah-langkah untuk mengalami } \\
\text { tugas yang kompleks. Mener- } \\
\text { jemahkan equaton menjadi } \\
\text { Spreadsheet komputer } \\
\text { Kata Kunci: memahami, } \\
\text { mengubah, diagram, membela, } \\
\text { membedakan, memperkirakan, } \\
\text { menjelaskan, meluas, menya- } \\
\text { maratakan, memberi } \\
\text { contoh, menyimpulkan, } \\
\text { menafsirkan, parafrase, prediksi, } \\
\text { penulisan ulang, } \\
\text { merangkum, menerjemahkan } \\
\text { Teknologi: buat analogi, } \\
\text { berpartisipasi dalam koperasi } \\
\text { belajar, membuat catatan, cerita } \\
\text { pemberitaan }\end{array}$ & $\begin{array}{l}\text { Memahami: } \\
\text { Memahami } \\
\text { artinya, } \\
\text { terjemahan, } \\
\text { interpolasi, } \\
\text { dan inter- } \\
\text { pretasi dari } \\
\text { instruksi dan } \\
\text { masalah. } \\
\text { Sebutkan } \\
\text { masalah } \\
\text { dalam diri } \\
\text { seseorang } \\
\text { kata-kata } \\
\text { sendiri. }\end{array}$ & $\begin{array}{l}\text { Contoh: Tulis ulang } \\
\text { prinsip-prinsip tes menulis, } \\
\text { Jelaskan sendiri langkah } \\
\text { untuk melakukan tugas yang } \\
\text { kompleks. Terjemahkan } \\
\text { persamaan ke dalam } \\
\text { spreadsheet komputer. } \\
\text { Kata Kunci: memahami, } \\
\text { bertobat, membela, } \\
\text { membedakan, } \\
\text { memperkirakan, } \\
\text { menjelaskan, memperluas, } \\
\text { menggeneralisasikan, memberi } \\
\text { sebuah contoh, } \\
\text { menyimpulkan, menafsirkan, } \\
\text { parafrase, prediksi, penulisan } \\
\text { ulang, } \\
\text { merangkum, menerjemahkan } \\
\text { Teknologi: buat analogi, } \\
\text { berpartisipasi dalam } \\
\text { pembelajaran kooperatif, } \\
\text { membuat catatan, } \\
\text { mendongeng, cari di Intermet }\end{array}$ \\
\hline $\begin{array}{l}\text { Aplikasi: } \\
\text { Gunakan } \\
\text { konsep baru } \\
\text { situasi atau } \\
\text { penggu- } \\
\text { naan tanpa } \\
\text { kompromi } \\
\text { dari sebuah } \\
\text { abstraksi. } \\
\text { Terapkan apa } \\
\text { itu belajar } \\
\text { di kelas ke } \\
\text { dalam situasi } \\
\text { maya di In- } \\
\text { ternet } \\
\text { tempat kerja. }\end{array}$ & $\begin{array}{l}\text { Contoh: Gunakan manual } \\
\text { untuk menghitung waktu } \\
\text { liburan karyawan. Menerapkan } \\
\text { undang-undang statistik untuk } \\
\text { mengevaluasi keandalan suatu } \\
\text { Tes tertulis. } \\
\text { Kata Kunci: berlaku, peruba- } \\
\text { han, Menghitung, konstruk, } \\
\text { menunjukkan, menemukan, } \\
\text { memanipulasi, memodifikasi, } \\
\text { mengoperasikan, memprediksi, } \\
\text { menyiapkan, memproduksi, } \\
\text { menghubungkan, menunjukkan, } \\
\text { memecahkan, menggunakan } \\
\text { Teknologi: kolaborasi pembe- } \\
\text { lajaran, membuat proses, blog, } \\
\text { praktek }\end{array}$ & $\begin{array}{l}\text { Aplikasi: } \\
\text { Gunakan } \\
\text { konsep baru } \\
\text { situasi atau } \\
\text { penggunaan } \\
\text { abstraksi } \\
\text { tanpa kom- } \\
\text { promi. } \\
\text { Terapkan apa } \\
\text { itu dipelajari } \\
\text { dalam kelas } \\
\text { menjadi } \\
\text { situasi baru } \\
\text { di tempat } \\
\text { kerja. }\end{array}$ & $\begin{array}{l}\text { Contoh: Gunakan manual un- } \\
\text { tuk menghitung waktu liburan } \\
\text { karyawan. Menerapkan } \\
\text { hukum statistik untuk } \\
\text { mengevaluasi keandalan tes } \\
\text { tertulis. } \\
\text { Kata Kunci: berlaku, pe- } \\
\text { rubahan, hitung, konstruk, } \\
\text { pertunjukkan, menemukan, } \\
\text { memanipulasi, memodifikasi, } \\
\text { mengoperasikan, mempredik- } \\
\text { si, menyiapkan, menghasilkan, } \\
\text { menceritakan, menunjukkan, } \\
\text { memecahkan, menggunakan } \\
\text { Teknologi: pembelajaran } \\
\text { kolaboratif, buat proses, blog, } \\
\text { praktik }\end{array}$ \\
\hline
\end{tabular}




\begin{tabular}{|c|c|c|c|}
\hline \multicolumn{2}{|c|}{ Domain Kognitif Tua (Asli) } & \multicolumn{2}{|c|}{ Domain Kognitif Baru (Revisi) } \\
\hline $\begin{array}{l}\text { Analisis: } \\
\text { Pisahkan } \\
\text { bahan atau } \\
\text { konsep } \\
\text { menjadi } \\
\text { komponen } \\
\text { bagian seh- } \\
\text { ingga } \\
\text { organisasi } \\
\text { struktur } \\
\text { mungkin } \\
\text { dimengerti. } \\
\text { Bedakan } \\
\text { antara fakta } \\
\text { dan kesim- } \\
\text { pulan }\end{array}$ & $\begin{array}{l}\text { Contoh: Memecahkan masalah } \\
\text { peralatan dengan menggunakan } \\
\text { logika deduksi. Kenali logis } \\
\text { fallacy in reasoning. Gathers } \\
\text { informasi dari departemen } \\
\text { memilih tugas yang diperlukan } \\
\text { untuk membedakan, men- } \\
\text { gidentifikasi, mengilustrasikan, } \\
\text { menyimpulkan, menguraikan, } \\
\text { menghubungkan, pelatihan. } \\
\text { Kata Kunci: analisis, istirahat } \\
\text { turun, bandingkan, kontras, } \\
\text { diagram, mendekonstruksi, } \\
\text { membedakan, memisahkan, } \\
\text { memilih, memisahkan } \\
\text { Teknologi: fishbowls, } \\
\text { berdebat, mempertanyakan apa } \\
\text { terjadi, jalankan tes }\end{array}$ & $\begin{array}{l}\text { Menganalisa: } \\
\text { Bahan yg } \\
\text { terpisah } \\
\text { atau konsep } \\
\text { menjadi } \\
\text { bagian dari } \\
\text { komponen } \\
\text { organisasi } \\
\text { agar dimen- } \\
\text { gerti. } \\
\text { Membedakan } \\
\text { antara fakta } \\
\text { dan } \\
\text { kesimpulan. }\end{array}$ & $\begin{array}{l}\text { Contoh: Pecahkan masalah } \\
\text { peralatan dengan menggu- } \\
\text { nakan deduksi logis. } \\
\text { Kenali kesalahan logis dalam } \\
\text { alasan, informasi Gathcrs dari } \\
\text { departemen dan memilih yang } \\
\text { diperlukantugas-tugas untuk } \\
\text { pelatihan } \\
\text { Kata-kata Kunci: analisis, } \\
\text { penguraian, Membandingkan, } \\
\text { kontras, diagram, } \\
\text { mendekonstruksi, membeda- } \\
\text { kan, } \\
\text { membedakan, membedakan, } \\
\text { mengidentifikasi, mengilus- } \\
\text { trasikan, menyimpulkan, } \\
\text { menguraikan, } \\
\text { menghubungkan, memilih, } \\
\text { memisahkan } \\
\text { Teknologi: fishbowls, debat- } \\
\text { ing, mempertanyakan apa } \\
\text { yang terjadi, jalankan sebuah } \\
\text { tes }\end{array}$ \\
\hline $\begin{array}{l}\text { Sintesis: Ban- } \\
\text { gun struktur } \\
\text { atau pola } \\
\text { dari beragam } \\
\text { elemen. Pas- } \\
\text { ang bagian } \\
\text { bersama } \\
\text { untuk } \\
\text { membentuk } \\
\text { secara utuh, } \\
\text { dengan } \\
\text { penekanan } \\
\text { pada mem- } \\
\text { buat arti/ } \\
\text { struktur yang } \\
\text { baru. }\end{array}$ & $\begin{array}{l}\text { Contoh: Tulis perusahaan } \\
\text { operasi atau proses manual. } \\
\text { Desain mesin untuk melakukan } \\
\text { tugas spesifik. Pelatihan terpadu } \\
\text { dari beberapa sumber untuk } \\
\text { menyelesaikan masalah. Merevisi } \\
\text { dan memproses untuk tingkat- } \\
\text { kan hasilnya. } \\
\text { Kata Kunci: mengkategorikan, } \\
\text { menggabungkan, menyusun, } \\
\text { menyusun, menciptakan, meran- } \\
\text { cang, mendesain, } \\
\text { menjelaskan, menghasilkan, } \\
\text { memodifikasi, mengorganisir, } \\
\text { merencanakan, mengatur ulang, } \\
\text { merekonstruksi, menghubung- } \\
\text { kan, menata ulang, merevisi, } \\
\text { menulis ulang, meringkas, } \\
\text { memberitahu, menulis } \\
\text { Teknologi: esai, jejaring }\end{array}$ & $\begin{array}{l}\text { Mengeval- } \\
\text { uasi: Buat } \\
\text { Penilaian } \\
\text { tentang nilai } \\
\text { gagasan } \\
\text { atau bahan. }\end{array}$ & $\begin{array}{l}\text { Contoh: Pilih larutan yang } \\
\text { paling efektif. Sewa yang pal- } \\
\text { ing berkualitas. Jelaskan dan } \\
\text { gunakan anggaran yang baru. } \\
\text { Kata Kunci: menilai, mem- } \\
\text { bandingkan, } \\
\text { menyetujui, mempertentang- } \\
\text { kan, mengkritik, mengkritik, } \\
\text { membela, menjelaskan, } \\
\text { mendiskriminasi, mengevalua- } \\
\text { si, menjelaskan, } \\
\text { menafsirkan, membenarkan, } \\
\text { menceritakan, merangkum, } \\
\text { mendukung } \\
\text { Teknologi: survei, blog }\end{array}$ \\
\hline
\end{tabular}




\begin{tabular}{|c|c|c|c|}
\hline \multicolumn{2}{|c|}{ Domain Kognitif Tua (Asli) } & \multicolumn{2}{|c|}{ Domain Kognitif Baru (Revisi) } \\
\hline $\begin{array}{l}\text { Evalua- } \\
\text { si: Buat } \\
\text { penilaian } \\
\text { tentang ide } \\
\text { atau bahan. }\end{array}$ & $\begin{array}{l}\text { Contoh: Pilih yang paling } \\
\text { banyak solusi efektif. Pilih paling } \\
\text { banyak kandidat yang memenuhi } \\
\text { syarat. Jelaskan dan } \\
\text { membenarkan anggaran baru. } \\
\text { Kata Kunci: menilai, memband- } \\
\text { ingkan, } \\
\text { menyimpulkan, kontras, } \\
\text { mengkritik, kritik, membela, } \\
\text { menjelaskan, mendiskriminasi, } \\
\text { mengevaluasi, menjelaskan, } \\
\text { menafsirkan, membenarkan, } \\
\text { menceritakan, merangkum, } \\
\text { mendukung } \\
\text { Teknologi: survei, blogging }\end{array}$ & $\begin{array}{l}\text { Mencip- } \\
\text { takan: Mem- } \\
\text { bangun } \\
\text { struktur atau } \\
\text { pola dari } \\
\text { beragam } \\
\text { elemen. } \\
\text { Pasang bagian } \\
\text { bersama } \\
\text { untuk mem- } \\
\text { bentuk secara } \\
\text { utuh, dengan } \\
\text { penekanan } \\
\text { pada mem- } \\
\text { buat arti/ } \\
\text { struktur yang } \\
\text { baru }\end{array}$ & $\begin{array}{l}\text { Contoh: Tulis operasi peru- } \\
\text { sahaan atau proses manual. } \\
\text { Desain mesin untuk melaku- } \\
\text { kan tugas tertentu. } \\
\text { Integrasikan pelatihan dari } \\
\text { beberapa sumber untuk me- } \\
\text { mecahkan masalah. Merevisi } \\
\text { dan proses untuk meningkat- } \\
\text { kan hasilnya. } \\
\text { Kata Kunci: mengkategori- } \\
\text { kan, menggabungkan, } \\
\text { mengkompilasi, menyusun, } \\
\text { membuat, merancang, } \\
\text { mendesain, menjelaskan, } \\
\text { menghasilkan, memodifikasi, } \\
\text { mengorganisir, merencanakan, } \\
\text { mengatur ulang, merekon- } \\
\text { struksi, menghubungkan, me- } \\
\text { nata ulang, merevisi, menulis } \\
\text { ulang, merangkum, memberi } \\
\text { tahu, Menulis } \\
\text { Teknologi: buat model baru, } \\
\text { Menulis esai, berjejaring den- } \\
\text { gan orang lain }\end{array}$ \\
\hline
\end{tabular}

(Anderson et al., 2001)

Dimensi Pengetahuan pada taksonomi Bloom juga mengalami perubahan (revisi). Adapun perubahan yang disampaikan oleh Anderson et al. (2001) dapat dijabarkan pada tabel 3 . 
Tabel 3. Revisi Taksonomi Bloom Dimensi Pengetahuan

\begin{tabular}{|c|c|}
\hline Dimensi Pengetahuan Lama & Dimensi Pengetahuan Baru (Revisi) \\
\hline $\begin{array}{l}\text { 1. Pengetahuan Faktual } \\
\text { a. Pengetahuan tentang } \\
\text { terminologi (label, simbol } \\
\text { verbal dan non verbal } \\
\text { b. Pengetahuan tentang bagian } \\
\text { detail dan unsur-unsurnya } \\
\text { (peristiwa, tempat, orang, } \\
\text { tanggal, hari, sumber } \\
\text { informasi) } \\
\text { 2. Pengetahuan Konseptual } \\
\text { a. Pengetahuan tentang } \\
\text { klasifikasi dan kategori (Jenis, } \\
\text { tipe, pola, macam) } \\
\text { b. Pengetahuan tentang prinsip } \\
\text { dan generalisasi } \\
\text { c. Pengetahuan tentang teori } \\
\text { (definisi, pengertian), model, } \\
\text { dan struktur } \\
\text { 3. Pengetahuan Prinsip } \\
\text { Pengetahuan tentang hukum, } \\
\text { kaidah, rumus, aturan. } \\
\text { 4. Pengetahuan Prosedural } \\
\text { a. Pengetahuan cara melakukan } \\
\text { sesuatu } \\
\text { b. Pengetahuan tentang } \\
\text { rangkaian langkah yang harus } \\
\text { diikuti (mekanisme, tahapan, } \\
\text { prosedur) }\end{array}$ & $\begin{array}{l}\text { 1. Pengetahuan Faktual } \\
\text { a. Pengetahuan tentang } \\
\text { terminologi } \\
\text { b. Pengetahuan tentang bagian } \\
\text { detail dan unsur-unsurnya } \\
\text { 2. Pengetahuan Konseptual } \\
\text { a. Pengetahuan tentang } \\
\text { klasifikasi dan kategori } \\
\text { b. Pengetahuan tentang prinsip } \\
\text { dan generalisasi } \\
\text { c. Pengetahuan tentang teori, } \\
\text { model, dan struktur } \\
\text { 3. Pengetahuan Prosedural } \\
\text { a. Pengetahuan tentang } \\
\text { keterampilan khusus yang } \\
\text { berhubungan dengan } \\
\text { suatu bidang tertentu dan } \\
\text { pengetahuan algoritma } \\
\text { b. Pengetahuan tentang teknik } \\
\text { dan metode } \\
\text { c. Pengetahuan tentang kriteria } \\
\text { penggunaan suatu prosedur } \\
\text { 4. Pengetahuan Metakognitif } \\
\text { c. Pengetahuan strategik } \\
\text { d. Pengetahuan tentang operasi } \\
\text { kognitif } \\
\text { e. Pengetahuan tentang diri } \\
\text { sendiri }\end{array}$ \\
\hline
\end{tabular}

Dimensi pengetahuan mencakup spesifikasi domain, pengalaman, konteks sosial dalam proses membangun dan mengembangkan sebuah pengetahuan. Empat jenis pengetahuan tersebut membantu guru dalam merancang dam memutuskan materi apa yang akan disampaikan pada siswa. Berdasarkan tabel di atas, kita bisa analisis terdapat perubahan pada dimensi pengetahuan/ empat jenis pengetahuan yang disampaikan oleh Anderson et al. 
(2001), yaitu:

1. Dimensi pengetahuan secara berurutan mengalami perubahan yaitu dari dimensi pengetahuan lama yang terdiri dari dimensi faktual, konseptual, prinsip, dan prosedural berubah secara berurutan menjadi faktual, konseptual, prosedural, metakognisi.

2. Tipe pengetahuan prinsip digabungkan dengan tipe pengetahuan konseptual. dimana dimensi pengetahuan yang baru ditambahkan yaitu tipe pengetahuan metakognisi sebagai tipe pengetahuan keempat.

Taksonomi baru ini atau revisi taksonomi Bloom ini mencerminkan bentuk pemikiran yang lebih aktif dan lebih akurat.

Selain dimensi pengetahuan yang mengalami perubahan, dimensi proses kognitif juga mengalami perubahan juga. Dimensi proses kognitif merupakan klasifikasi proses-proses kognitif siswa secara komprehensif yang terdapat dalam tujuan-tujuan bidang pendidikan. Berikut dijelaskan perubahan dimensi proses kognitif oleh Anderson et al. (2001).

\section{Tabel 4. Revisi Taksonomi Bloom Dimensi Proses Kognitif}

\section{Dimensi Proses Kognitif Lama \\ Dimensi Proses Kognitif Baru}

\section{A. Pengetahuan}

Kemampuan menghafal verbal atau mengingat kembali materi pembelajaran yang sudah dipelajari dari guru, buku, atau sumber lain tanpa melakukan perubahan tentang pengetahuan hafalan berupa fakta, konsep, prinsip, dan prosedur.

\section{B. Pemahaman}

Kemampuan mengolah pengetahuan yang dipelajari menjadi sesuatu yang baru, seperti mengganti kata dengan sinonim, menulis kembali sesuatu dengan gaya sendiri, mengubah bentuk komunikasi dari tulisan ke tabel atau visual, memberi tafsir terhadap sesuatu hal.
A. Pengetahuan

Mengingat dan mengenali kembali pengetahuan, fakta, dan konsep, dari yang sudah dipelajari. Sub kategori proses mengingat dapat berupa menentukan, mengetahui, memberi label, mendaftar, menjodohkan, mencantumkan, mencocokkan, memberi nama, mengenali, memilih, mencari.

\section{B. Memahami}

Membangun makna atau memaknai pesan pembelajaran, termasuk dari apa yang diucapkan, dituliskan, dan digambar". Sub kategori proses dari memahami adalah menafsirkan, mencontohkan, mendeskripsikan, merangkum, menyimpulkan, membandingkan, dan menjelaskan. 
Dimensi Proses Kognitif Lama

C. Aplikasi

Kemampuan untuk menggunakan materi yang telah dipelajari pada situasi atau kondisi real (sebenarnya). Aplikasi disini dapat diartikan sebagai penerapan atau penggunaan hukum-hukum, rumus, metode dan prinsip dalam konteks atau situasi yang lain.

\section{Dimensi Proses Kognitif Baru}

\section{Mengaplikasikan}

Menggunakan ide dan konsep yang telah dipelajari untuk memecahkan masalah pada situasi atau kondisi real (sebenarnya). Aplikasi disini dapat diartikan sebagai penerapan atau penggunaan hukum-hukum, rumus, metode dan prinsip dalam konteks atau situasi yang lain. Sub kategori proses mengaplikasikan adalah menerapkan, menghitung, mendramatisasi, memecahkan, menemukan, memanipulasi, memodifikasi, mengoperasikan, memprediksi, mengimplementasikan, memecahkan.

\section{Analisis}

Kemampuan menggunakan informasi

D. Menganalisis

Menggunakan informasi untuk mengklasifikasi, mengelompokkan, menentukan hubungan suatu informasi dengan informasi lain, antara fakta dan konsep, argumentasi dan kesimpulan. Sub kategori proses menganalisis adalah mengedit, mengkategorikan, membandingkan, membedakan, menggolongkan, memerinci, mendeteksi, menguraikan suatu objek, mendiagnosis, merelasikan, menelaah.

\section{E. Sintesis}

Kemampuan untuk meletakkan atau menghubungkan bagian-bagian di dalam suatu bentuk keseluruhan yang baru; Kemampuan untuk menyusun formulasi baru dari formulasi-formulasi yang ada. Misalnya dapat menyusun, dapat merencanakan, dapat meringkaskan dan dapat menyesuiakan terhadap suatu teori atau rumusan-rumusan yang telah ada

\section{E. Mengevaluasi}

Menilai suatu objek, suatu benda, atau informasi dengan kriteria tertentu. Sub kategori untuk mengevaluasi adalah membuktikan, memvalidasi, memproyeksi, mereview, mengetes, meresensi, memeriksa, mengritik. 
Dimensi Proses Kognitif Lama

\section{F. Evaluasi}

Kemampuan menilai suatu objek, suatu benda, atau informasi dengan kriteria tertentu.

\section{Dimensi Proses Kognitif Baru}

\section{F. Mencipta}

Meletakkan atau menghubungkan bagian-bagian di dalam suatu bentuk keseluruhan yang baru; menyusun formulasi baru dari formulasi-formulasi yang ada. Sub kategori untuk mencipta adalah menghasilkan, merencanakan, menyusun, mengembangkan, menciptakan, membangun, memproduksi, menyusun, merancang, membuat.

Ada dua hal yang diubah dalam dimensi proses kognitif. Pertama, perubahan urutan tingkatan proses kognitif sintesis dan evaluasi, dan perubahan penamaan tingkatan sintesis. Kedua, simbolisasi dari penamaan proses kognitif dari nomina menjadi verb. Anderson et al. (2001) mengusulkan dimensi proses kognitif baru menjadi: mengingat, memahami, mengaplikasikan, menganalisis, mengevaluasi, dan mencipta. Proses kognitif sintesis menjadi mencipta dan ditempatkan sebagai urutan yang tertinggi dalam proses kognitif.

Dari perubahan atau revisi yang telah disampaikan baik perubahan dimensi pengetahuan dan perubahan dimensi proses kognitif, maka diperoleh ada hubungan atau interaksi di antara kedua dimensi tersebut. Anderson et al. (2001) merumuskan interaksi antara dimensi pengetahuan dan perubahan dimensi proses kognitif sebagai berikut:

\section{Tabel 5. Interaksi Revisi Dimensi Pengetahuan dengan Dimensi Proses Kognitif}

\begin{tabular}{|c|c|c|c|c|c|c|}
\hline & \multicolumn{6}{|c|}{ Dimensi Proses Kognitif } \\
\hline & $\begin{array}{c}\text { C1 } \\
\text { Mengingat }\end{array}$ & $\begin{array}{c}\text { C2 } \\
\text { Memahami }\end{array}$ & $\begin{array}{c}\text { C3 } \\
\text { Menerapkan }\end{array}$ & $\begin{array}{c}\text { C4 } \\
\text { Menganalisis }\end{array}$ & $\begin{array}{c}\text { C5 } \\
\text { Mengevaluasi }\end{array}$ & $\begin{array}{c}\text { C6 } \\
\text { Mencipta }\end{array}$ \\
\hline Pengetahuan & $\mathrm{C} 1$ & $\mathrm{C} 2$ & C3 & $\mathrm{C} 4$ & C5 & C6 \\
\hline Faktual & Faktual & Faktual & Faktual & Faktual & Faktual & Faktual \\
\hline Pengetahuan & $\mathrm{C} 1$ & $\mathrm{C} 2$ & C3 & $\mathrm{C} 4$ & C5 & C6 \\
\hline Konseptual & Konseptual & Konseptual & Konseptual & Konseptual & Konseptual & Konseptual \\
\hline Pengetahuan & $\mathrm{C} 1$ & $\mathrm{C} 2$ & C3 & $\mathrm{C} 4$ & C5 & C6 \\
\hline Prosedural & Prosedural & Prosedural & Prosedural & Prosedural & Prosedural & Prosedural \\
\hline
\end{tabular}


Humanika, Kajian IImiah Mata Kuliah Umum, Vol. 21. No. 2. (2021), 151-172

\begin{tabular}{|c|c|c|c|c|c|c|}
\hline & \multicolumn{6}{|c|}{ Dimensi Proses Kognitif } \\
\hline & $\begin{array}{c}\text { C1 } \\
\text { Mengingat } \\
\end{array}$ & $\begin{array}{c}\text { C2 } \\
\text { Memahami } \\
\end{array}$ & $\begin{array}{c}\text { C3 } \\
\text { Menerapkan } \\
\end{array}$ & $\begin{array}{c}\text { C4 } \\
\text { Menganalisis } \\
\end{array}$ & $\begin{array}{c}\text { C5 } \\
\text { Mengevaluasi } \\
\end{array}$ & $\begin{array}{c}\text { C6 } \\
\text { Mencipta } \\
\end{array}$ \\
\hline Pengetahuan & $\mathrm{C} 1$ & $\mathrm{C} 2$ & C3 & $\mathrm{C} 4$ & C5 & C6 \\
\hline Metakognitif & Metakognitif & Metakognitif & Metakognitif & Metakognitif & Metakognitif & $\begin{array}{c}\text { Metakog- } \\
\text { nitif }\end{array}$ \\
\hline
\end{tabular}

\section{Tabel 6. Daftar contoh kata kerja operasional yang dapat dipakai untuk domain Kognitif}

\begin{tabular}{|c|c|c|c|c|c|}
\hline Mengetahui & Memahami & Mengaplikasikan & Menganalisis & Mengevaluasi & Membuat/Create \\
\hline Mengutip & Memperkirakan & Menugaskan & Menganalisis & Membandingkn & Mengabstraksi \\
\hline Menyebutkan & Menjelaskan & Mengurutkan & Mengaudit & Menyimpulkan & Mengatur \\
\hline Menjelaskan & Mengkategori- & Menentukan & Memecahkan & Menilai & Manganimasi \\
\hline Menggambar & kan & Menerapkan & Menegaskan & Mengarahkan & Mengumpulkan \\
\hline Membilang & Mencirikan & Menyesuaikan & Mendeteksi & Mengkritik & Mengategorikan \\
\hline Mengidentifikasi & Merinci & Mengkalkulasi & Mendiagnosis & Menimbang & Mengkode \\
\hline Mendaftar & Mengasosiasikan & Memodifikasi & Menyeleksi & Memutuskan & Mengombinasikan \\
\hline Menunjukkan & Membandingkan & Mengklasifiksi & Memerinci & Memisahkan & Menyusun \\
\hline Memberi label & Menghitung & Membangun & Menominasikan & Memprediksi & Mengarang \\
\hline Memberi indeks & Mengkontraskan & Mengurutkan & Mendiagram- & Memperjelas & Membangun \\
\hline Memasangkan & Mengubah & Membiasakan & kan & Menugaskan & Menaggulangi \\
\hline Menamai & Mempertahank- & Mencegah & Mengkorelasikn & Menafsirkan & Menghubungkan \\
\hline Manandai & an & Menggambarkan & Merasionalkan & Mempertahakn & Menciptakan \\
\hline Membaca & Menguraikan & Menggunakan & Menguji & Memerinci & Mengkreasikan \\
\hline Menyadari & Menjalin & Menilai & Mencerahkan & Mengukur & Mengkoreksi \\
\hline Menghafal & Membedakan & Melatih & Menjelajah & Merangkum & Merancang \\
\hline Meniru & Mendiskusikan & Menggali & Membagankan & Membuktikan & Merencanakan \\
\hline Mencatat & Menggali & Mengemukakan & Menyimpulkan & Memvalidasi & Mendikte \\
\hline Mengulang & Mencontohkan & Mengadaptasi & Menemukan & Mengetes & Meningkatkan \\
\hline Mereproduksi & Menerangkan & Menyelidiki & Menelaah & Mendukung & Memperjelas \\
\hline Meninjau & Mengemukakan & Mengoperasikan & Memaksilmalkn & Memilih & Memfasilitasi \\
\hline Memilih & Mempolakan & Mempersoalkan & Memerintahkan & memproyeksikn & Membentuk \\
\hline Menyatakan & Memperluas & Mengkonsepkan & Mengedit & & Merumuskan \\
\hline Mempelajari & Menyimpulkan & Melaksanakan & Mengaitkan & & Menggeneralisasi \\
\hline Mentabulasi & Meramalkan & Meramalkan & Memilih & & Menggabungkan \\
\hline Memberi kode & Merangkum & Memproduksi & Mengukur & & Memadukan \\
\hline Menelusuri & Menjabarkan & Memproses & Melatih & & Membatas \\
\hline Menulis & & & Mentransfer & & Mereparasi \\
\hline
\end{tabular}

Berdasarkan tabel interaksi dimensi pengetahuan dan dimensi proses kognitif, maka guru dapat mengukur capaian pembelajaran yang akan ditetapkan pada proses pembelajaran yang akan dilaksanakan. Dalam rangka 
mengoperasionalkan tujuan pembelajaran yang ingin dicapai pada domain kognitif, maka ada beberapa contoh kata kerja operasional yang dapat digunakan oleh guru (Anderson et al., 2010).

\section{Domain Afektif}

Krathwohl et al., (1964) menyatakan bahwa domain afektif merupakan domain yang meliputi rasa, nilai, apresiasi, antusiasme, motivasi, dan sikap. Kompetensi siswa yang mencerminkan afeksi yang baik dapat terlihat dari sikap kedewasaan yang sesuai dengan usia dan perkembangan siswa dan tercermin pada perilaku/ attitude sehari-hari pada proses pembelajaran baik di dalam kelas maupun di luar kelas. Ada beberapa contoh perilaku yang mencerminkan sikap/afeksi yang baik dari siswa, seperti disiplin dalam menjalankan semua kewajibannya terkait proses pembelajaran, bertanggung jawab atas apa yang dilakukan, semangat dan antusias dalam mengikuti pembelajaran, menghormati serta menghargai guru dan teman sebaya, dan sebagainya.

Domain kognitif dalam kurikulum 2013 muncul secara eksplisit pada kompetensi sikap spiritual dan sosial. Sikap spiritual ini diwujudkan agar siswa memiliki kepribadian yang beriman, bertakwa, dan bersyukur kepada Tuhan yang Maha Esa. Sedangkan untuk sikap sosial pada kurikulum 2013 ditunjukkan dengan pembentukan pribadi siswa yang berakhlak mulia, mandiri, demokratis, dan bertanggung jawab (Kemendikbud, 2014).

Kemampuan afektif, khususnya sikap, dari mahasiswa dapat diketahui kecenderungan, perubahan, dan perkembangannya dengan mendasarkan pada jenis-jenis kategori domain afektif, seperti yang dikemukakan oleh Krathwohl et al., (1964) berikut ini.

1. Tingkat Menerima

Tingkat di mana mahasiswa memiliki keinginan menerima atau memperhatikan (Reciving atau Attending) suatu rangsangan atau stimulus yang diberikan dalam bentuk persoalan, situasi, fenomena, dan sebagainya. Contoh kemampuan dalam tingkat menerima adalah mahasiswa bersedia untuk mendengarkan temannya yang berbicara dengan respek.

2. Tingkat Menanggapi

Tingkat di mana mahasiswa mereaksi atau menanggapi (Responding) suatu rangsangan atau stimulus yang diberikan dalam bentuk persoalan, situasi, fenomena, dan sebagainya. Contoh kemampuan dalam tingkat menanggapi adalah mahasiswa aktif berpartisipasi dalam diskusi kelompok, seperti memberikan penjelasan dan menanggapi pendapat dari teman. 
3. Tingkat Menghargai

Tingkat di mana mahasiswa menunjukkan kesediaan menerima dan menghargai (valuing) suatu nilai-nilai yang disodorkan kepadanya. Contoh kemampuan dalam tingkat menghargai adalah mengajukan rencana untuk perbaikan kehidupan masyarakat.

4. Tingkat Menghayati

Tingkat di mana mahasiswa menjadikan nilai-nilai yang disodorkan itu sebagai bagian internal dalam dirinya, menjadikan nilai-nilai itu prioritas dalam dirinya (Organization). Contoh kemampuan dalam tingkat menginternalisasi adalah memprioritaskan waktu untuk belajar, membantu teman, dan sebagainya.

5. Tingkat Mengamalkan

Tingkat di mana mahasiswa menjadikan nilai-nilai itu sebagai pengendali perilakunya dalam kehidupan sehari-hari sehingga menjadi gaya hidup (Characterization). Contoh kemampuan dalam tingkat mengamalkan adalah menunjukkan sikap mandiri ketika bekerja.

Krathwohl et al., (1964), menyampaikan tentang Level Domain Afektif sebagai berikut:

\section{Bagan 1: Level Domain Afektif}

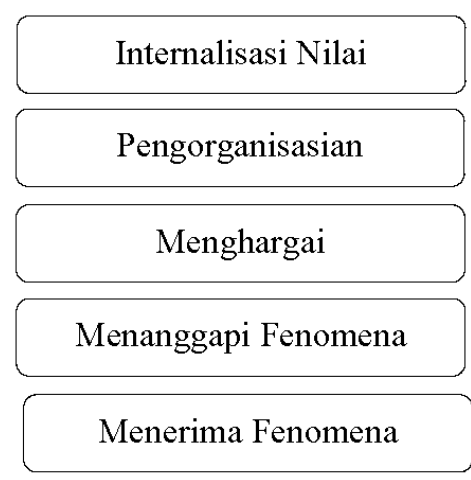

Selain itu, Gaol \& Jimmy (2014) juga mengoperasionalkan tujuan pembelajaran yang ingin dicapai pada domain afektif, sehingga ada beberapa contoh kata kerja operasional yang dapat digunakan oleh guru. 
Tabel 7. Level Domain Afektif dengan Contoh dan Kata Kunci

\begin{tabular}{|c|c|}
\hline Level & Contoh dan Kata Kuci \\
\hline $\begin{array}{l}\text { Menerima fenomena: Kesediaan } \\
\text { kesadaran untuk mendengar, memilih } \\
\text { perhatian }\end{array}$ & $\begin{array}{l}\text { Contoh: Dengarkan orang lain dengan } \\
\text { hormat. Dengarkan dan ingat nama } \\
\text { orang-orang yang baru diperkenalkan. } \\
\text { Kata kunci: Pengetahuan, Tanya, ikuti, } \\
\text { memberi, mendengarkan, memahami }\end{array}$ \\
\hline $\begin{array}{l}\text { Menanggapi fenomena: Partisipasi } \\
\text { aktif dari pihak peserta didik. hadir dan } \\
\text { bereaksi terhadap fenomena tertentu. } \\
\text { Hasil belajar dapat menekankan } \\
\text { kepatuhan dalam merespons, kemauan } \\
\text { untuk merespons, atau kepuasan dalam } \\
\text { merespons (motivasi) }\end{array}$ & $\begin{array}{l}\text { Contoh: berpartisipasi dalam diskusi } \\
\text { kelas. Berikan sebuah presentasi. } \\
\text { Mempertanyakan model konsep cita-cita } \\
\text { baru, dll agar dapat sepenuhnya dipahami. } \\
\text { Tahu aturan dan praktik keselamatan itu. } \\
\text { Kata kunci: Jawaban, assist, kepatuhan, } \\
\text { diskusi, salam, bantuan, label, kinerja, } \\
\text { hadiah, memberi tahu. }\end{array}$ \\
\hline
\end{tabular}

Valuing: Nilai atau nilai seseorang Contoh: Tunjukkan keyakinan pada yang melekat pada objek, fenomena, proses demokrasi. Sensitif terhadap atau perilaku tertentu. Ini berkisar dari perbedaan individu dan budaya penerimaan yang sederhana hingga (keragaman nilai). Menunjukkan komitmen yang lebih kompleks. Menilai kemampuan untuk menyelesaikan besaran berdasarkan internalisasi masalah. Mengusulkan rencana seperangkat nilai-nilai tertentu, perbaikan sosial dan menindaklanjutinya sementara petunjuk untuk nilai-nilai ini dengan komitmen. Menginformasikan diekspresikan dalam perilaku terbuka manajemen tentang hal-hal yang sangat pelajar dan sering dapat diidentifikasi. dirasakan seseorang.

Kata-kata tajam: menghargai, harta, mendemonstrasikan, memulai, mengundang, bergabung, membenarkan, mengusulkan, menghormati, berbagi

Pengorganisasian: Pengorganisasian Contoh: Mengenali kebutuhan
nilai-nilai menjadi prioritas dengan keseimbangan antara kebebasan dan membandingkan nilai-nilai yang perilaku yang bertanggung jawab. berbeda, menyelesaikan konflik di Menjelaskan peran perencanaan sistematis antara itu, dan menciptakan sistem nilai dalam memecahkan masalah. Menerima yang unik. Penekanannya adalah pada standar etika profesional. Membuat membandingkan, menghubungkan, dan rencana kehidupan yang selaras dengan mensintesis nilai-nilai. kemampuan, minat, dan kepercayaan. Memprioritaskan waktu secara efektif untuk memenuhi kebutuhan organisasi, keluarga, dan diri.

Kata kunci: membandingkan, menghubungkan, mensintesis 


\begin{tabular}{ll}
\hline Level & Contoh dan Kata Kuci \\
\hline Nilai internalisasi & (karakterisasi). Contoh: Tunjukkan kemandirian saat \\
Memiliki sistem nilai yang mengontrol & bekerja tanpa batas. bekerja sama dalam \\
perilaku mereka. Tingkah lakunya kegiatan kelompok (menampilkan kerja & The \\
meresap, konsisten, dapat diprediksi, dan & tim). Gunakan pendekatan objektif \\
yang paling penting adalah pembelajar. & dalam pemecahan masalah. menampilkan \\
Tujuan instruksional berkaitan dengan & komitmen profesional untuk praktik \\
pola umum siswa penyesuaian (pribadi, & etis setiap hari. Merevisi penilaian dan \\
sosial, emosional) & mengubah perilaku dalam terang bukti \\
& baru. Nilai orang untuk apa mereka, \\
& bukan bagaimana mereka terlihat. \\
& Kata-kata kunci: tindakan, diskriminasi, \\
& tampilan, pengaruh, modifikasi, kinerja, \\
& kualifikasi, pertanyaan, revisi, servis, \\
penyelesaian, virifies.
\end{tabular}

\section{Domain Psokomotorik}

Taksonomi Bloom yang dituangkan pada buku I dan II tidak menyebut tentang doman psikomotorik. Domain psikomotorik tercetus oleh pemikiran Simpson (1966) yang menyatakan bahwa kemampuan psikomotorik berkaitan fisik, koordinasi, dan penggunaan bidang keterampilan motorik yang harus dilatih secara terus menerus dan diukur dari segi kecepatan, presisi, jarak, prosedur, atau teknik dalam eksekusinya. Simpson mendefinisikan kemampuan psikomotik tersebut didasarkan pada penelitian di bidang pendidikan industrial, pertanian, ekonomi rumah tangga, pendidikan bisnis, musik, seni, dan olah raga.

Simpson (1972) menyampaikan terdapat tujuh aktifitas untuk mengkategorikan kemampuan psikomotorik yang dimulai dari yang paling sederhana meningkat menjadi ke hal yang rumit. Kategori tersebut terdiri dari (1) persepsi, (2) kesiapan, (3) meniru, (4) membiasakan, (5) mahir, (6) alami, dan (7) orisinal. Tokoh lain yang mengkaji tentang kemampuan psikomotik yaitu Dave (1967) yang membagi kemampuan psikomotik dalam 5 tingkatan, yaitu (1) meniru, (2) memanipulasi, (3) presisi, (4) artikulasi, dan (5) naturalisasi. Kategori kemampuan psikomotorik yang disampaikan oleh dua tokoh di atas, saat ini dipergunakan untuk mengukur kegiatan pembelajaran yang melibatkan fisik, motorik, dan kinestetik, seperti olah raga, seni musik, seni rupa, seni tari, drama, percobaan dalam sains.

Ada beberapa contoh kegiatan yang termasuk ke dalam kategori domain 
psikomotorik seperti: (1) mendemonstrasikan (2) memerankan (3) melakukan (4) menggunakan alat (5) mempresentasikan (6) membuat produk dua atau tiga dimensi (7) merangkai dan (8) memodifikasi.

Simpson dan Dave merumuskan kemampuan psikomotorik lebih kepada kemampuan kongkrit. Sedangkan jika cermati, ada beberapa kemampuan yang sifatnya abstrak tetapi masuk ke dalam domain psikomotorik. Kemampuan psikomotorik yang bersifat abstrak seperti: menulis, membaca, menghitung, menggambar, dan mengarang dalam bidang bahasa, sosial, dan agama, yang kurang melibatkan fisik, motorik, dan kinestetik, serta lebih banyak melibatkan abstraksi, inovasi, dan kreativitas (Dyer. Et al., 2011). Taksonomi Dyer, dkk terdiri dari: (1) mengamati, (2) menanya, (3) mencoba, (4) menalar, dan (5) mengkomunikasikan yang tertuang dalam konsep The five key "discovery skills" yang meliputi Associating, Questioning, Observing, experimenting, dan Networking.

Simpson (1972), Dave (1967), dan Dyer. Etal., (2011) mengoperasionalkan tujuan pembelajaran yang ingin dicapai pada domain psikomotorik, sehingga ada beberapa contoh kata kerja operasional yang dapat digunakan oleh guru.

\section{Tabel 8. Kata Kerja Operasional untuk Domain Psikomotorik Kongkret}

\begin{tabular}{ll}
\hline Tingkat Psikomotorik & Kata Kerja Operasional \\
\hline Meniru & mencoba, menyalin, mengikuti (gerakan), menduplikasi, \\
& meniru. \\
\hline Membiasakan & merakit, membuat, mengkalibrasi, membangun, \\
& membongkar, menampilkan, membedah, mengencangkan, \\
& memperbaiki, menggiling, memanaskan, memanipulasi, \\
& mengukur, memperbaiki, mencampur, mengatur, membuat \\
& sketsa \\
\hline Mahir & merakit, membangun, mengkalibrasi, membangun, \\
& membongkar, menampilkan, mengikat, memperbaiki, \\
& menggiling, memanaskan, memanipulasi, mengukur, \\
& memperbaiki, mencampur, mengatur, membuat sketsa \\
& (bedanya dengan tingkat membiasakan, tingkat ini \\
& menunjukkan bahwa kinerjanya lebih cepat, lebih baik, \\
& lebih akurat, dll. \\
\hline menyesuaikan, mengubah, mengubah, mengatur ulang, \\
mereorganisasi, merevisi, bervariasi
\end{tabular}




\begin{tabular}{ll}
\hline Tingkat Psikomotorik & Kata Kerja Operasional \\
\hline Tindakan Orisinal & $\begin{array}{l}\text { menyusun, membangun, menggabungkan, membuat, } \\
\text { membuat, merancang, memulai, membuat, berasal }\end{array}$ \\
\hline \multicolumn{1}{c}{ Tabel 8. Kata Kerja Operasional untuk Domain Psikomotorik Abstrak } \\
\hline Tingkat Psikomotorik & Kata Kerja Operasional \\
\hline Mengamati & $\begin{array}{l}\text { melihat, mendengar, membaca, menyimak, } \\
\text { merasakan, mencermati, dan mengidentifikasi, }\end{array}$ \\
\hline Menanya & $\begin{array}{l}\text { menanyakan (secara lisan), menuliskan } \\
\text { pertanyaan, mendiskusikan, bertanya jawab. }\end{array}$ \\
\hline Mencoba & $\begin{array}{l}\text { melakukan percobaan, mencari informasi, } \\
\text { membaca, melakukan wawancara }\end{array}$ \\
\hline Menalar & $\begin{array}{l}\text { menyimpulkan, menghubungkan, mengasosiasi, } \\
\text { mengklasifikasikan, mencari hubungan sebab } \\
\text { akibat. }\end{array}$ \\
\hline Mengkomunikasikan & $\begin{array}{l}\text { mempresentasikan, menulis (laporan), memamer- } \\
\text { kan. }\end{array}$ \\
\hline
\end{tabular}

\section{Simpulan}

Revisi taksonomi Bloom muncul diakibatkan adanya tuntutan perkembangan dunia pendidikan yang bergerak sangat cepat dalam rangka menciptakan sumber daya manusia yang berkualitas. Revisi taksonomi Bloom berusaha membantu dunia pendidikan melalui penyusunan perangkat pembelajaran berupa RPP yang sarat akan instruksi ketercapaian tujuan pembelajaran melalui penggunaan kata kerja yang tepat. Saat ini perkembangan ilmu pengetahuan dan teknologi melalui era revolusi industri 4.0 menuntuk siswa tidak hanya sampai pada tahap evaluasi, akan tetapi di dorong agar siswa mampu sampai ke level creating (mencipta) pada domain kognitif, mampu memiliki sikap dan perilaku yang baik saat pembelajaran di dalam kelas maupun di luar kelas secara jujur (domain afeksi), dan memiliki fisik yang tangguh dan kuat (domain psikomotik) agar tujuan pembelajaran tercapai.. 


\section{Daftar Pustaka}

Anderson, L.W., Krathwohl, D.R. (2001). A Taxonomy for Learning, Teaching, and Assesing: A Revision of Bloom's Taxonomy of Educatioanl Objectives. New York: Addison Wesley Longman, Inc.

Dave, R. (1967). Psychomotor domain. International Conference of Educational Testing.

Departemen Pendidikan Nasional. (2005). Undang-Undang Nomor 14 Tahun 2005, Tentang Guru dan Dosen. Depdiknas.

Depdiknas. (2003). Undang-undang RI No.20 tahun 2003.tentang sistem pendidikan nasional.

Dimyati \& Mudjiono. (2015) Belajar dan pembelajaran. Rineka Cipta

Gaol, CHR. Jimmy L. (2014). A to Z Human Capital (Manajemen Sumber Daya Manusia) Konsep, Teori, dan Pengembangan dalam Konteks Organisasi Publik dan Bisnis, PT. Gramedia Widiasarana.

Kemendikbud. (2014). Konsep dan Implementasi Kurikulum 2013. Kementrian Pendidikan dan Kebudayaan.

Krathwohl, B.S. Bloom, B.B Masia. (1964). Taxonomy of Educational Objectives. The Classification of Educational Goals, Handbook II: Affective Domain. David McKay Company, Inc.

Krathwohl, D. R. (2002). A Revision of Bloom's Taxonomy: An Overview. Theory Into Practice, 41(4)

Lorin W. Anderson dan David R. Krathwohl (2010). Kerangka Landasan untuk Pembelajaran, Pengajaran dan asesmen Revisi Taksonomi Bloom. Pustaka, Belajar: Yogyakarta.

Simpson, E.J. (1966). The classification of educational objectives in the psychomotor domain. The Psychomotor Domain. 3:43-56. Gryphon House.

Simpson, E.J. (1972). The classification of educational objectives in the psychomotor domain. The Psychomotor Domain. 3:43-56. Gryphon House.

Zhou, Molly. Brown, David. (2017). Educational Learning Theories: 2nd Edition. Galileo, University System of Georgia. Galileo Open Learning Materials.

Winkel, W.S. (2007). Psikologi pengajaran. Media Abadi. 
Humanika, Kajian IImiah Mata Kuliah Umum, Vol. 21. No. 2. (2021), 151-172 